\title{
RESPONSE OF SOME SUGAR BEET VARIETIES TO FOLIAR SPRAYING WITH COMPOST TEA AND ITS RELATIONSHIP WITH TWO SUGAR BEET INSECTS, BEET FLY, (Pegomya mixta Vill.) AND TORTOISE BEETLE (Cassida vittata Vill.) UNDER NEWLY RECLAIMED SANDY SOIL
}

\author{
M. M. Abd El-Rahman (1), A.A. Abo El-Ftooh(2) and M. A. Ghonema ${ }^{(3)}$ \\ (1) Department of Agricultural Physiology and chemistry; (2) Department of Sugar Crops \\ Diseases\& Pests and (3) Genetic and Breeding Department, \\ Sugar Crops Research Institute, Agriculture Research Center, 12619, Giza, Egypt.
}

Received: Nov. 21, 2016

Accepted: Dec. 26, 2016

\begin{abstract}
Two field experiments were carried out in $\mathrm{km} 71$ West Alexandria- Cairo desert Road during 2014/15 and 2015/16 seasons to study the response of some multigerm sugar beet varieties i.e., Top, Sultan and Kawemira to foliar spray with compost tea at three levels of (0, 15 and $20 \mathrm{~L} / \mathrm{fed} / 300 \mathrm{~L}$ water) at 45 and 75 days from sowing. The experimental design was a split plot design with three replicates, foliar spray with compost tea levels were arranged in the main plots and sugar beet varieties were allocated in the sub plots. The results showed that foliar spray with the level of 20 L/fed with compost tea significantly increased root length, diameter, fresh weight/plant, sucrose\%, purity\%, root and sugar yields/fed in both seasons, while, decreased root mineral contents ( $\alpha$ amino $N, \mathrm{Na}$ and $\mathrm{K} \%$ ) as compared with zero treatment (control) or $15 \mathrm{~L} / \mathrm{fed}$ level of compost tea.

The Three tested varieties were differed significantly in the root length, diameter, fresh weight/plant, sucrose $\%$, purity\%, root and sugar yields/fed and root mineral contents. Kawemira variety surpassed the other two varieties (Sultan and Top) in the most traits in both seasons.

Foliar spray with compost tea increased the numbers of two sugar beet insects, beet fly (Pegomya mixta Vill.) and tortoise beetle (Cassida vittata Vill.). Kawemira variety was less attracted by the two previous insects, during two successive seasons.

Moreover foliar spray with compost tea at level 20 L/fed recorded the highest values for sucrose $\%$, root and sugar yields/fed in both seasons. Generally, it could be recommended that sown Kawemira, Sultan and Top varieties, respectively and sprayed with $20 \mathrm{~L} / \mathrm{fed}$ compost tea produced the highest sucrose\%, root and sugar yields/fed and yield quality in a sandy soil.
\end{abstract}

Key words: compost tea - varieties of sugar beet - sugar beet insects.

\section{INTRODUCTION}

Sugar beet plays a prominent role in sugar production. It is one of the most important sugar crops in the world. It ranks the second important sugar crops after sugar cane, producing annually about $40 \%$ of sugar production all over the world. In Egypt, it becomes the first source of sugar and shares $57 \%$ from total sugar production (sugar crops council 2016). It has been a large importance where there are wide newly reclaimed sandy soils (Mekki, 2014). Compost tea are compost - derived liquid products that may potentially induce positive effects on treated crops, including disease suppers sevens (defensibility) and bio stimulation of the overall improved plant status (pane et al. 2016). Compost tea is generally used in two ways: for plant disease treatment and for plant nutrition and growth promotion (Ganesan et al. 2015). In Egypt, El-Gizawy et al. 2014 found that sugar yield and Juice quality characteristics of sugar beet were significantly increased with compost tea treatments.

Also, there is great interest among sustainable growers about the use of 
compost tea for increased crop health and fertility. Compost tea extracts prepared from composted manure, an organic farm composted, or cattle yard wastes, applied as foliar sprays, compost tea is used for two reasons: to inoculate microbial life into the soil or onto the foliage of plants and to add soluble nutrients to the foliage or to the soil to feed the organisms and the plants present. (Steve, 2009) Compost Tea revealed significant positive effects on tomato yield, biomass, and number of fruits in comparison to the control. (El-Hanafi Septi, 2005) moreover Compost Tea was used for controlling nematode, Meloidogyne Javanca (Maareg et al. 1999 ), disease Botrytis Cinerea (Welke 2005) and decreased nymphal survival when compost tea was applied to egg masses of Halyomorpha halys ( Mathews and Barry 2014 ). Badr and Hilal (2009) found that foliar application of sugar beet plants with compost tea once time significantly surpassed those sprayed twice or three times compared to control plants in root and sugar yields (ton/fed), sucrose $\%$.

Egyptian Government imports about 0.5 million ton of sugar, every year (Sugar Crops Council, 2016), to face the rapid increase of population. All sugar beet genotypes cultivated in Egypt are imported from foreign countries, so, it is preferable to evaluate them under Egyptian conditions especially under newly reclaimed soil, to evaluate them under different sowing dates and different harvesting dates to select the best suited ones. The differences between varieties in gene make up expression may be throwing some light on the relative importance of studying varieties behavior through the growing season. Osman et al. (2003) in Egypt, showed that Kawemira variety was superior in sucrose $\%$, root and sugar yields/fed compared to Top, Lola and Pleno varieties. Aly (2006) found that Marathon variety surpassed significantly the other varieties for root length, diameter, fresh weight, root and sugar yields/fed. While, Kawemira variety was the best for sucrose $\%$, purity $\%$, extractable sugar $\%$ and extractability\%. Ismail et al. (2006 \& 2007) indicated that sugar beet genotypes differed significantly in growth, yield and quality characteristics in two seasons. Khalil (2010), Enan et al (2009), and Shalaby et al. (2008) tested several sugar beet varieties that differed significantly in root weight/plant, and sugar yields/fed in both seasons.

The aim of this, investigation, to study the effect of foliar spray with compost tea on yield and quality of some sugar beet varieties as well as the infestation with the main key sugar beet insects (Pegomya mixta Vill. and Cassida vittata Vill.).

\section{MATERIALS AND METHODS}

Two field experiments were carried out in a sandy loam soil at $\mathrm{km} 71$ West AlexandriaCairo desert Road during 2014/15 and 2015/16 seasons to study the response of some multigerm sugar beet varieties i.e., Top, Sultan and Kawemira to foliar spray with compost tea at three levels $(0,15$ and $20 \mathrm{~L} / \mathrm{fed} / 300 \mathrm{~L}$ water).

The experimental design was a split plot design with three replications, foliar spray with compost tea levels were arranged in the main plots and sugar beet varieties in the sub plots. Compost Tea sprayed after 45 and 75 days from sowing. Compost tea is a liquid produced by leaching soluble nutrients and extracting bacteria from compost. Chemical analysis of compost tea in Table 1, Compost tea in commercial name, was provided from Microbiology Department, Agriculture Research Center, Ministry of Agriculture, Egypt. Plot size was $15.0 \mathrm{~m}^{2}$ consists of 5 ridges, $6 \mathrm{~m}$ long, $50 \mathrm{~cm}$ apart and $20 \mathrm{~cm}$ between hills spacing. Plants were sowing in the $15^{\text {th }}$ of October in both seasons and harvested when the outside leaves of these plants turned yellow (after 210 days from sowing). The previous crop was maize in both seasons. Nitrogen fertilizer at the rate of $80 \mathrm{~kg} \mathrm{~N} / \mathrm{fed}$ was added in the form of ammonium nitrate $(33.5 \% \mathrm{~N})$ in two equals doses, the $1^{\text {st }}$ one 
after thinning and the other was applied at 2week interval after the first application. A fixed dose of phosphorus was added in the form of calcium super phosphate (15.5\% $\mathrm{P}_{2} \mathrm{O}_{5}$ ) at the rate of $100 \mathrm{~kg} \mathrm{P}_{2} \mathrm{O}_{5} / \mathrm{fed}$ during land preparation. Potassium fertilizer was added in the form of potassium sulfate (48\% $\mathrm{K}_{2} \mathrm{O} / \mathrm{fed}$ ) at the rate of $50 \mathrm{~kg} / \mathrm{fed}$ with the first dose of nitrogen fertilizer. Other agricultural practices required for growing sugar beet were carried out as usually practiced in the region. Some physical and chemical properties of the experimental soil were analyzed according to Jakson (1967) in Table 2.

\section{Recorded data:}

At harvest, ten plants were taken at random from each plot were harvested to determine the following traits:

\section{A. Vegetative traits:}

1. Root length (cm/plant).

2. Root diameter (cm/plant).

3. Root fresh weight (g/plant)

\section{B. Quality traits:}

Samples of ten roots were taken randomly, from each plot as fully cleaned roots and sent to Nile Sugar Company Lab to determine the following traits:

- Sucrose \%

- Juice purity \%
- $\mathrm{Na}, \mathrm{K}$ and $\alpha$ amino $\mathrm{N}$ meq/100 g root

C. Productivity traits:

1. Root yield (ton/fed): plants of sugar beet from each plot were harvested topped to determine root yield as ton/fed on fresh weight basis.

2. Sugar yield (ton/fed) was calculated using the following equation:

Sugar yield $($ ton/fed $)=$ Root yield $x$ sucrose\%.

D. Population density of sugar beet insects:

The first sample of insect pests was taken after four weeks from sowing. Monthly, each sample consisted of fifteen sugar beet plants (5 plants / replicate), was randomly collected along the period of growing season. Each sample was put in plastic bag and was transported to the laboratory. At laboratory, a moistened cotton pieces with ether was placed in the plastic bag for anesthetizing insects. The sampled plants were carefully examined for counting the total of tortoise beetle Cassida vittata (adults and larvae) and beet fly (larvae) Pegomya mixta.

The collected data were statistically analyzed according to Snedecor and Cochran (1981).

Table 1: Chemical analysis of the tested compost tea

\begin{tabular}{|c|l|l|l|l|l|l|l|l|l|l|}
\hline EC $\left(\mathrm{dSm}^{-1}\right)$ & $\mathrm{pH}$ & $\mathrm{C}$ & O.M & $\mathrm{N}$ & $\mathrm{P}$ & $\mathrm{K}$ & $\mathrm{Fe}$ & $\mathrm{Mn}$ & $\mathrm{Zn}$ & $\mathrm{Cu}$ \\
\cline { 2 - 11 } & & \multicolumn{9}{|c|}{$(\%)$} \\
\hline 2.75 & 7.33 & 12.0 & 31.0 & 1.89 & 0.54 & 2.31 & 122 & 76.0 & 53.0 & 31.0 \\
\hline
\end{tabular}

Table 2: Some physical and chemical properties of the experimental soil

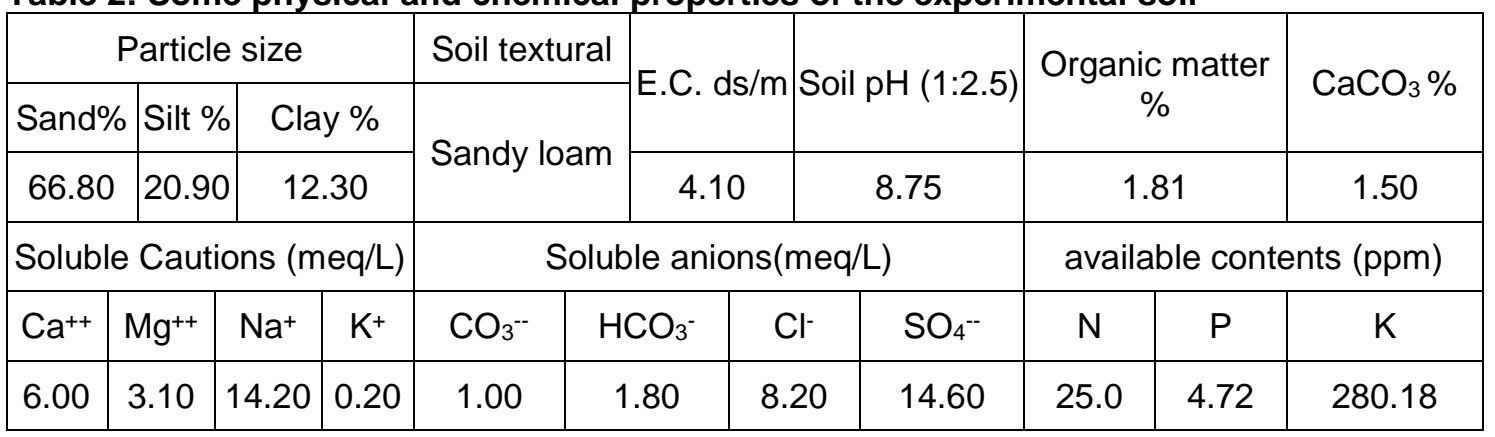




\section{RESULTS AND DISCUSSION I. Compost tea effects:}

The results in Table 3 showed that application of compost tea at the level of 20 (L/fed) was more effective than 0 or 15 (L/fed), where, it gave the highest values for root length, diameter, fresh weight/plant, sucrose $\%$, purity $\%$ and yields of root and sugar/fed, while, it gave the lowest values for root minerals contents ( $\alpha$ amino $\mathrm{N}, \mathrm{Na}$ and $\mathrm{K} \%$ ).

The increase in plant growth traits i.e. root length, diameter, fresh weight/plant and yields might be due to excessive vegetative growth by increasing foliar application levels of compost tea up to two sprays. Also, the increase in quality may be due to higher sucrose $\%$ and decreasing mineral contents led to increase in sugar yield/fed. The obtained results are in accordance with that reported by Steve (2009) who reported that compost tea led to decrease root mineral contents in root juice or improved the life in the soil and on plant surface. Also, similar results are coincided with those finding to El-
Hanafi (2005), Badr and Hilal (2009) and ElGizawy et al. (2014).

\section{Varietal differences:}

Results in Table 4 indicated that three sugar beet varieties significantly differed in the growth traits sucrose \% yields/fed and minerals content in both seasons. Kawemira was the best variety than Sultan and Top where, it gave the highest values of (average root length, diameter, fresh weight/plant, sucrose $\%$, purity $\%$, root and sugar yields/fed) and the lowest values of the tested root minerals content percentage, i.e. $\alpha$ amino $\mathrm{N} \%, \mathrm{Na} \%$ and $\mathrm{K} \%$.

This result might be due to the organic matter formed by photosynthesis, minerals $\%$ were lower and surplus sugars formed by photosynthesis for Kawemira variety were more than Sultan and Top varieties and the structure of gene make up. These results are in agreement with reported by Aly (2006), El-Sheikh et al. (2009), Enan et al. (2009), Khalil (2010) and El-Gizawy et al. (2014).

Table 3: Effect of foliar compost Tea on growth, quality, yields and root mineral contents at harvest during $2014 / 15$ and $2015 / 16$ seasons.

\begin{tabular}{|c|c|c|c|c|c|c|c|c|c|c|}
\hline \multicolumn{11}{|c|}{$2014 / 15$ season } \\
\hline \multirow{2}{*}{$\begin{array}{l}\text { Compost } \\
\text { Tea L/fed }\end{array}$} & \multicolumn{3}{|c|}{ Growth traits } & \multicolumn{2}{|c|}{ Quality\% } & \multicolumn{3}{|c|}{ Root minerals content } & \multicolumn{2}{|c|}{$\begin{array}{c}\text { Yields } \\
\text { (ton/fed) }\end{array}$} \\
\hline & $\mathrm{RL}$ & RD & RFW & Suc.\% & Pur.\% & $\underset{\%}{\alpha \underset{\%}{\operatorname{amino}} \mathrm{N}}$ & $\mathrm{Na} \%$ & $\mathrm{~K} \%$ & RY & SY \\
\hline 0 & 29.26 & 12.50 & 916 & 15.35 & 76.75 & 1.81 & 1.50 & 5.39 & 27.42 & 4.21 \\
\hline 15 & 30.42 & 13.50 & 930 & 16.50 & 82.56 & 1.68 & 1.42 & 5.27 & 28.40 & 4.69 \\
\hline 20 & 31.00 & 13.90 & 1111 & 17.32 & 86.60 & 1.53 & 1.31 & 5.23 & 30.34 & 5.25 \\
\hline LSD at $5 \%$ & 0.44 & 0.35 & 15.00 & 0.33 & 0.95 & 0.03 & 0.10 & 0.11 & 0.85 & 0.02 \\
\hline \multicolumn{11}{|c|}{ 2015/16 season } \\
\hline 0 & 29.90 & 13.70 & 989 & 16.17 & 77.00 & 1.70 & 1.62 & 5.41 & 27.07 & 438 \\
\hline 15 & 31.20 & 14.14 & 1067 & 17.19 & 81.86 & 1.53 & 1.55 & 5.29 & 28.83 & 4.95 \\
\hline 20 & 32.80 & 16.09 & 1104 & 18.25 & 86.90 & 1.40 & 1.42 & 5.14 & 30.13 & 5.50 \\
\hline LSD at $5 \%$ & 0.16 & 0.22 & 15.00 & 0.21 & 0.87 & 0.03 & 0.12 & 0.09 & 0.66 & 0.02 \\
\hline
\end{tabular}

$\mathrm{RL}=$ root length $(\mathrm{cm}), \mathrm{RD}=$ Root diameter $(\mathrm{cm}), \mathrm{RFW}=$ root fresh weight (g/plant), Suc\%.= Sucrose\%, Pur. $\%=$ Purity $\%, \alpha$ amino $\mathrm{N}, \mathrm{Na}$ and $\mathrm{K} \%=\alpha$ amino $\mathrm{N}$, sodium and potassium percentage.

$\mathrm{RY}=\mathrm{Root}$ yield/fed and $\mathrm{SY}=$ Sugar yield/fed . 
Response of some sugar beet varieties to foliar spraying with

Table 4: Effect of varieties on growth, quality \%, yields and root mineral contents at harvest during 2014/15 and 2015/16 seasons.

\begin{tabular}{|c|c|c|c|c|c|c|c|c|c|c|}
\hline \multicolumn{10}{|c|}{$\begin{array}{c}\text { Sugar beet } \\
\text { varieties }\end{array}$} & \multicolumn{3}{|c|}{ Growth traits } & \multicolumn{2}{c|}{ Quality\% } & \multicolumn{2}{c|}{ Minerals content } & \multicolumn{2}{c|}{$\begin{array}{c}\text { Yields } \\
\text { (ton/fed) }\end{array}$} \\
\cline { 2 - 12 } & RL & RD & RFW & Suc.\% & Pur.\% & $\begin{array}{c}\alpha \text { amino N } \\
\%\end{array}$ & Na\% & K\% & RY & SY \\
\hline Top & 29.00 & 12.50 & 932 & 15.50 & 77.50 & 1.77 & 1.50 & 5.70 & 26.82 & 4.16 \\
\hline Sultan & 30.30 & 13.20 & 970 & 16.52 & 82.60 & 1.69 & 1.41 & 5.34 & 28.78 & 4.75 \\
\hline Kawemira & 31.40 & 14.20 & 1055 & 17.16 & 85.80 & 1.55 & 1.33 & 4.85 & 30.56 & 5.26 \\
\hline LSD at 5\% & 0.65 & 0.35 & 25.05 & 0.25 & 0.75 & 0.06 & 0.08 & 0.23 & 0.95 & 0.10 \\
\hline & & & $2015 / 16$ season & & & & \\
\hline Top & 29.70 & 13.53 & 948 & 16.24 & 77.33 & 1.82 & 1.61 & 5.60 & 26.57 & 4.31 \\
\hline Sultan & 31.30 & 14.75 & 1062 & 17.07 & 81.29 & 1.50 & 1.53 & 5.24 & 28.82 & 4.92 \\
\hline Kawemira & 32.90 & 15.65 & 1150 & 18.30 & 87.14 & 1.31 & 1.45 & 5.00 & 30.64 & 5.61 \\
\hline LSD at 5\% & 0.85 & 0.56 & 30.25 & 0.15 & 1.35 & 0.02 & 0.05 & 0.13 & 0.77 & 0.04 \\
\hline
\end{tabular}

$\mathrm{RL}=$ root length $(\mathrm{cm}), \mathrm{RD}=$ Root diameter $(\mathrm{cm}), \mathrm{RFW}=$ root fresh weight $(\mathrm{g} /$ plant $)$, Suc. $=$ Sucrose $\%$, Pur.\% = Purity\%, $\alpha$ amino $\mathrm{N} \%, \mathrm{Na}$ and $\mathrm{K} \%=\alpha$ amino $\mathrm{N} \%$, sodium and potassium percentage. $\mathrm{RY}=$ Root yield/fed and $\mathrm{SY}=$ Sugar yield/fed

\section{Interaction effects:}

Data tabulated in Table 5 cleared that the interaction between foliar spray with compost tea levels and the three varieties significantly affected in sucrose\%, root and sugar yields/fed. Kawemira variety gave the highest values of obvious traits under all compost tea levels. The results also found that the highest sucrose $\%$, root and sugar yields/fed were obtained when sown Kawemira variety was sprayed with 20 L/fed compost tea as compared with other interactions in both seasons.

\section{Effects of composts tea levels on population density of two sugar beet insects:}

1. Beet fly (Pegomya mixta Vill.)
Data in Table (6) clear that the highest total number of beet fly was recorded by 20 L/fed (198 \& 269 larvae/plant) in the first and second season, respectively. While, the 0 L/fed was less attracted to beet fly $(171 \& 188$ larvae / plant) in two seasons. The mean numbers in same table observed that there were not significant between the $0 \mathrm{~L} /$ fed and $15 \mathrm{~L} / \mathrm{fed}$ in the first season. However, there was significant differences among the three mean compost tea levels $(0,15$ and 20 L/fed) which was recorded 26.86, 33.0 and 38.43 larvae, respectively in the second season. These results were harmony with Abo El-Ftooh et. al. (2012) who found that using bio-fertilizers increased the number of beet fly. Data in (Table 6) showed also that the peak numbers of beet fly was obtained during March 40, 40 and 45 larvae /plant (in 
Abd El-Rahman, et al.,

the first season) and 55, 59 and 62 larvae /plant (in the second season) for 0,15 and $20 \mathrm{~L}$ compost tea/fed, respectively. This result agrees with Abo El-Ftooh (2002) and Kandil (2016) who found that maximum numbers was recorded in March. The increasing of the tested insects under foliar spray with compost tea maybe return to the compost tea contains 31\% organic matter and $1.89 \%$ nitrogen. These components increased the dose of nitrogen fertilizer, which may produce lush green plants (Gotyal et al. 2016) or it smell, which attracts these insects.

\section{Tortoise beetle (Cassida vittata Vill.)}

Data in Table (6) showed that $C$. vittata stated appeared in January in the first season while in the second season after applied the compost tea .The 20L/fed/300 L water was recorded the highest total number $153 \& 166$ larvae and adults /plant in the first and second seasons, respectively. On the other hand, the lowest total numbers were recorded (95 \&105 larvae and adults /plant) at $0 \mathrm{~L} /$ fed in the first and second seasons, respectively. The $15 \mathrm{~L} / \mathrm{fed} / 300 \mathrm{~L}$ water level in the second season was less attracted to C. vittata through interval studied. This is due to the first number was registered in February at second season (9 larvae and adults /plant) which was less than the same period in the first season (22 larvae and adults /plant). This results agree with Abo El Ftooh et al (2007) and Kandil (2016) who found that the $C$. vittata was appeared in January and February. However, there were no significant differences for interaction between varieties and compost tea levels.

Table 5: Interaction between varieties and foliar application of compost tea on Sucrose\%, Root yields and Sugar yields at harvest during 2014/15 and 2015/16 seasons.

\begin{tabular}{|c|c|c|c|c|c|c|c|c|c|c|}
\hline \multirow{2}{*}{$\begin{array}{c}\text { Sugar bee } \\
\text { varieties }\end{array}$} & \multicolumn{7}{|c|}{ Sucrose\% } & \multicolumn{7}{c|}{ Root yields (ton/fed) } & \multicolumn{2}{c|}{ Sugar yields (ton/fed) } \\
\cline { 2 - 10 } & 0 & 15 & 20 & 0 & 15 & 20 & 0 & 15 & 20 \\
\hline Top & 14.30 & 15.45 & 16.75 & 25.12 & 26.11 & 29.23 & 3.59 & 4.03 & 4.90 \\
\hline Sultan & 15.65 & 16.80 & 17.10 & 27.57 & 28.35 & 30.42 & 4.31 & 4.76 & 5.20 \\
\hline Kawemira & 16.10 & 17.25 & 18.11 & 29.57 & 30.75 & 31.37 & 4.73 & 5.28 & 5.65 \\
\hline LSD at 5\% & & 0.35 & & & 0.10 & & 0.16 & \\
\hline & & & & $2015 / 16$ season season & \\
\hline Top & 15.00 & 16.23 & 17.50 & 24.45 & 26.75 & 28.50 & 3.67 & 4.34 & 4.99 \\
\hline Sultan & 15.75 & 17.35 & 18.10 & 27.21 & 29.09 & 30.15 & 4.29 & 5.05 & 5.46 \\
\hline Kawemira & 17.76 & 17.99 & 19.15 & 29.55 & 30.62 & 31.74 & 5.18 & 5.46 & 6.05 \\
\hline LSD at 5\% & & 0.50 & & & 0.45 & & 0.18 \\
\hline
\end{tabular}


Table (6): The effect of compost tea levels on population's density of $P$. mixta Vill. and $C$. vittata Vill. during 2014/15 and 2015/16 seasons.

\begin{tabular}{|c|c|c|c|c|c|c|c|}
\hline \multirow{3}{*}{$\begin{array}{c}\text { Sugar beet } \\
\text { insects }\end{array}$} & \multirow{3}{*}{ Months } & \multicolumn{6}{|c|}{ Foliar application with Tea compost } \\
\hline & & \multicolumn{3}{|c|}{$2014 / 15$ season } & \multicolumn{3}{|c|}{ 2015/16 season } \\
\hline & & $\begin{array}{l}0 \mathrm{~L} / 300 \mathrm{~L} \\
\text { water/fed }\end{array}$ & $\begin{array}{l}15 \mathrm{~L} / 300 \mathrm{~L} \\
\text { water /fed }\end{array}$ & $\begin{array}{l}20 \mathrm{~L} / 300 \mathrm{~L} \\
\text { water/fed }\end{array}$ & $\begin{array}{l}0 \mathrm{~L} / 300 \mathrm{~L} \\
\text { water /fed }\end{array}$ & $\begin{array}{l}15 \mathrm{~L} / 300 \mathrm{~L} \\
\text { water/fed }\end{array}$ & $\begin{array}{c}20 \mathrm{~L} / 300 \mathrm{~L} \\
\text { water/fed }\end{array}$ \\
\hline \multirow{9}{*}{ 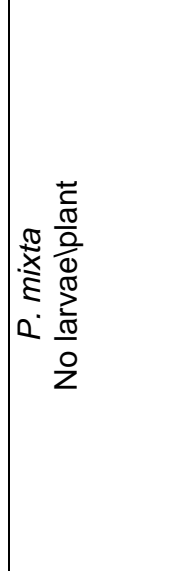 } & November & 10 & 0 & 0 & 9 & 10 & 14 \\
\hline & December & 21 & 25 & 30 & 22 & 28 & 33 \\
\hline & January & 28 & 31 & 33 & 29 & 31 & 34 \\
\hline & February & 39 & 41 & 44 & 33 & 38 & 46 \\
\hline & March & 40 & 40 & 45 & 55 & 59 & 62 \\
\hline & April & 22 & 25 & 28 & 30 & 43 & 50 \\
\hline & May & 11 & 15 & 18 & 10 & 22 & 30 \\
\hline & Total numbers & 171 & 177 & 198 & 188 & 231 & 269 \\
\hline & Mean & 24.43 & 25.29 & 28.29 & 26.86 & 33.00 & 38.43 \\
\hline \multicolumn{2}{|c|}{ LSD 0.05 between levels } & \multicolumn{3}{|c|}{$2.1 Y$} & \multicolumn{3}{|c|}{$2 . \cdot v$} \\
\hline \multicolumn{2}{|c|}{ LSD 0.05 between months } & \multicolumn{3}{|c|}{3.77} & \multicolumn{3}{|c|}{3.09} \\
\hline \multirow{9}{*}{ 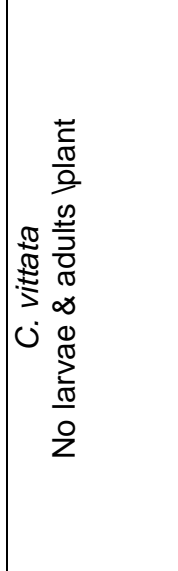 } & November & 0 & 0 & 0 & 0 & 0 & 0 \\
\hline & December & 0 & 0 & 0 & 0 & 0 & 0 \\
\hline & January & 3 & 6 & 10 & 0 & 0 & 0 \\
\hline & February & 11 & 22 & 20 & 12 & 9 & 20 \\
\hline & March & 21 & 30 & 32 & 25 & 36 & 40 \\
\hline & April & 24 & 32 & 42 & 30 & 36 & 48 \\
\hline & May & 36 & 45 & 49 & 38 & 51 & 58 \\
\hline & Total numbers & 95 & 135 & 153 & 105 & 132 & 166 \\
\hline & Mean & 13.57 & 19.29 & 21.86 & 15.00 & 18.86 & 23.71 \\
\hline \multicolumn{2}{|c|}{ LSD 0.05 between levels } & \multicolumn{3}{|c|}{2.09} & \multicolumn{3}{|c|}{$2 . r$} \\
\hline \multicolumn{2}{|c|}{ LSD 0.05 between months } & \multicolumn{3}{|c|}{3.11} & \multicolumn{3}{|c|}{$3 . \leqslant r$} \\
\hline
\end{tabular}

\section{Effect of varieties on the population density of sugar beet insects:}

\section{Beet fly ( $P$. mixta Vill.)}

Sugar beet is subjected to the attack by various insect pests which cause considerable damage to plant. Results obtained in the first and second seasons (Table 7) indicated that larvae of P. mixta was appeared after four weeks from sowing. There were significant differences between varieties and monthly rate of infection. During December the highest population density of this pest reached (26.33 and 26.00 larvae / plant) in Top variety in two winter seasons 2014/15 and 2015/16, respectively. This results agree with Abo ElFtooh (2002) and El-Zoghbey, (1999) who 
Abd El-Rahman, et al.,

found that the beet fly, $P$.mixta started to infest sugar beet plant after four weeks from sowing. The highest population density was reached (43.50 and 44.16 larvae/plant) in Sultan variety in March at the first and second seasons, respectively. The highest total number of population density was found in Top variety, whereas was more attracted (188.66 \& 196.32 larvae/plant) during first and second seasons, respectively. On the other hand Kawemira variety was less attracted $(114.3$ \& 150.98 larvae / plant) in first and second seasons, respectively.

Table (7): Effect of sugar beet varieties on populations density of $P$ mixta and $C$. vittata Vil. in 2014/15 and 2015/16 seasons.

\begin{tabular}{|c|c|c|c|c|c|c|c|}
\hline \multirow{3}{*}{$\begin{array}{l}\text { Sugar beet } \\
\text { insects }\end{array}$} & \multirow{3}{*}{ Months } & \multicolumn{6}{|c|}{ Sugar beet varieties } \\
\hline & & \multicolumn{3}{|c|}{ 2014/15 season } & \multicolumn{3}{|c|}{ 2015/16 season } \\
\hline & & Top & Sultan & Kawemira & Top & Sultan & Kawemira \\
\hline \multirow{9}{*}{ 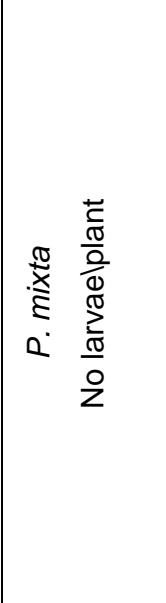 } & November & 16.5 & 9.16 & 6.65 & 8.16 & 9.33 & 2.66 \\
\hline & December & 26.33 & 18.66 & 18.5 & 26.00 & 18.66 & 21.83 \\
\hline & January & 29.33 & 33.66 & 25.00 & 32.83 & 34.16 & 26.33 \\
\hline & February & 38.00 & 37.16 & 27.83 & 39.00 & 37.50 & 28.00 \\
\hline & March & 40.83 & 43.5 & 34.66 & 44.00 & 44.16 & 42.00 \\
\hline & April & 23.00 & 23.16 & 21.33 & 28.33 & 23.33 & 20.33 \\
\hline & May & 14.67 & 14.00 & 10.33 & 18.00 & 13.50 & 9.83 \\
\hline & Total numbers & 188.66 & 179.30 & 114.3 & 196.32 & 180.64 & 150.98 \\
\hline & Mean & 26.95 & 25.61 & 16.33 & 28.04 & 25.80 & 21.57 \\
\hline \multicolumn{2}{|c|}{ LSD 0.05 between varieties } & \multicolumn{3}{|c|}{1.631} & \multicolumn{3}{|c|}{1.202} \\
\hline \multicolumn{2}{|c|}{ LSD 0.05 between months } & \multicolumn{3}{|c|}{3.89} & \multicolumn{3}{|c|}{3.02} \\
\hline \multirow{9}{*}{ 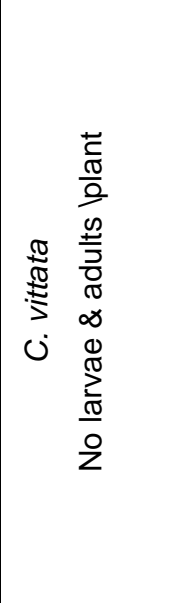 } & November & 0 & 0 & 0 & 0 & 0 & 0 \\
\hline & December & 12.00 & 5.00 & 3.50 & 5.50 & 2.50 & 0 \\
\hline & January & 13.00 & 1.50 & 11.50 & 11.00 & 8.50 & 8.50 \\
\hline & February & 30.00 & 31.50 & 18.50 & 39.00 & 35.00 & 26.00 \\
\hline & March & 50.50 & 46.00 & 32.00 & 54.50 & 46.16 & 39.00 \\
\hline & April & 56.50 & 52.50 & 37.00 & 61.50 & 58.00 & 51.00 \\
\hline & May & 63.50 & 62.00 & 45.00 & 68.50 & 66.00 & 57.5 \\
\hline & Total numbers & 225.5 & 198.5 & 147.5 & 240 & 216.16 & 182 \\
\hline & Mean & 32.21 & 28.36 & 21.07 & 34.28 & 30.88 & 26 \\
\hline \multicolumn{2}{|c|}{ LSD 0.05 between varieties } & \multicolumn{3}{|c|}{1.202} & \multicolumn{3}{|c|}{1.689} \\
\hline \multicolumn{2}{|c|}{ LSD 0.05 between months } & \multicolumn{3}{|c|}{3.26} & \multicolumn{3}{|c|}{3.84} \\
\hline
\end{tabular}




\section{Tortoise beetles (C. vittata Vill.)}

Data in Table (7) showed that significant differences among sugar beet varieties and monthly rate of infection. The obtained data in Table (7) for the first and second seasons illustrated that the infestation started in December in Top, Sultan and Kawemir varieties (12, 5 and 3.50$) \&(5.50,2.50$ and 0 larvae and adults /plant), respectively. The population density of $C$. vittata increased from February until May. The maximum total number was reached in May (63.50 and 68.50 larvae and adults/plant) in Top variety followed by (62 and 66 larvae and adults/plant) in Sultan variety followed by (45 and 57.5 larvae and adults/plant) in Kawemira variety in first and second seasons, respectively. These results are partly consistent with Salama and Elnagar (2002) who found that the outbreak of the tortoise beetle, Cassida vittata was observed in March to May. How ever these results differed with these of Abo El-Ftooh (2002) who reported that $C$. vittata started to infest sugar beet in February in two seasons. On the other hand, Kawemira variety was more tolerance to infest by $C$. vittata, the monthly means was (21.07 and 26 adults and larvae/ plant) in the first and second seasons, respectively. Top variety was more attracted to C. vittata (32.21 and 34.28 adults and larvae/ plant) followed by Sultan variety $(28.36 \& 30.88$ adults and larvae/ plant) in the first and second seasons, respectively.

Finally, it could be concluded that foliar spray with compost tea at level $20 \mathrm{~L} / \mathrm{fed}$ recorded the highest values for sucrose \%, root and sugar yields/fed in both seasons. Moreover, it could be recommended sowing Kawemira variety and foliar spray with 20 L/fed compost tea because of the highest sucrose $\%$, root and sugar yields/fed and yield quality in a sandy loam soil and it also gained less attracted by $P$. mixta and $C$. vittata Vill. Moreover foliar spray with compost tea increased the numbers of two sugar beet insects, beet fly $P$. mixta and tortoise beetle $C$. vittata.

\section{REFERENCES}

Abo El-Ftooh, A.A. (2002). Biological control to tortoise beetle Cassida Vittata Vill on sugar beet. Ph.D.Thesis, Fac. of Agric (Moshtoher), Zagazig. Univ., Egypt. 312 pp.

Abo El Ftooh, A. A., O. M. Badawy and M.M. Abd El Rahman (2007). Screening of nineteen new sugar beet (Beta vulgaris L.) varieties for the tortoise beetle, (Cassida vittata Vill.) resistance and yield at Nubaryia region, Egypt. J. Agric. Sci. Mansoura. Univ.,32(1): 653-660,2007

Abo El-Ftooh, A. A., K.M. Agami and M.M. Abd-El Rahman (2012). The effect of some organic manures and insecticides on sugar beet productivity and population dynamic of beet fly, Pegomya mixta vill.J. Plant Production, Mansoura Univ..3 (3): 557-569.

Aly, E.F. (2006). Effect of environmental conditions on productivity and quality of some sugar beet varieties. Ph. D. Thesis. Fac. of Agric. Benha Univ. Egypt.

Badr, A.I. and Samia M.M. Hilal (2009). Evaluation of injected ammonia and compost tea spraying on productivity of sugar beet. Minufiya J. Agric. Res. 34 (6): 2117-2129.

El-Gizawy, E., G. Shalaby and E. Mahmoud (2014). Effects of Tea Plant Compost and Mineral Nitrogen Levels on Yield and Quality of Sugar Beet Crop. Communications in Soil Science and Plant Analysis 45 (9): 1181-1194

El-Hanafi, S. K. (2005). Compost tea effects on soil fertility and plant growth of organic tomato (Selenium lycopersicum Mill) in comparison with different organic fertilizers. Thesis M.Sc. Italy. No 405

El-Sheikh, S.R.E., K.A.M. Khaled and S.A.A.M. Enan (2009). Evaluation of some sugar beet varieties under three harvesting dates. J. Agric. Sci., Mansoura Univ., 34 (3): 1559-1567.

El-Zoghbey, Amal A.A. (1999). Biological control of some sugar beet insects. Ph. D. Thesis, Fac. of Agric, Cairo. Univ., Egypt. 164 pp. 
Enan, S.A.A.M., S.R.E. El Sheikh and K.A.M. Khaled (2009). Evaluation of some sugar beet varieties under different levels of $\mathrm{N}$ and Mo fertilization. J. Biol. Chem. Environ. Sci., 4 (1): 345-362.

Ganesan, S., K. Vadivel and J. Jayaraman (2015). Sustainable Crop Disease Management using Natural Products. Book, Publisher: CABI, 424 pages

Gotyal, B.S., R.K. De, K. Selvaraj, S. Satpathy, Mukesh Kumar and P.N. Meena (2016). Effect of nitrogenous fertilizer on yellow mite infestation in Corchorus spp. Journal of Environmental Biology. 37, 431-436.

Ismail, A.M.A., A.H.S.A. Al-Laboody and N.M.S. Shalaby (2006). Variability and traits relationships in sugar beet under different sowing dates. Egypt. J. Plant Breeding, 10 (1): 387-406.

Ismail, A.M.A., A.H.S.A. Al-Laboody and N.M.S. Shalaby (2007). Evaluation of some sugar beet varieties under different combinations of NPK fertilizers. Egypt. J. Appl. Sci., 22 (3): 77-90.

Jakson, M. (1967). Soil Chem. Analyses. Prentice Hall Inc Englewood Cliff NJ USA.

Kandil, R.S. (2016). New trends for the control of Cassida vittata Vill and Pegomya mixta vill infesting sugar beet crop and assessment of yield in Nobaria region. Ph. D. Thesis, Agric., (SabaBasha) Alexandria Univ., Egypt, 93.pp

Khalil, Soha R.A.E. (2010). Study of performance and behavior of some sugar beet varieties under different environmental conditions. Ph.D. Thesis. Fac. Agric., Fayoum Univ., Egypt.

Maareg, M.F., Sohir T. Badr and B. A. Oteifa (1999). Effect of Two City Wastes Organic Composts, Fenamiphos and Ammonium Nitrate on Controlling Root Knot Nematode, Meloidogyne javanica and Productivity of Sugar beet. Egyptian Journal of Agronematology 3(1/2): 3(1/2): 95-113.

Mathews, C.R. and S. Barry (2014). Compost tea reduces egg hatch and early-stage nymphal development of Halyomorpha halys (Hemiptera: Pentatomidae). Fla Entomol 97(4):17261732

Mekki, B.B. (2014). Root Yield and Quality of Sugar Beet (Beta vulgaris L.) in Response to Foliar Application with Urea, Zinc and Manganese in Newly Reclaimed Sandy Soil. AmericanEurasian J. Agric. \& Environ. Sci., 14 (9): 800-806.

Osman, A.M.H., G.S. El-Sayed, M.S.H. Osman and K.S. El-Sogheir (2003). Soil application of some microelements with relation to yield and quality of sugar beet varieties. Annals of Agric. Sc., Moshtohor, 41 (3): 1071-1088.

Pane, C. , A. M. Palese, Ri. Spaccini, A. Piccolo, G. Celano and M. Zaccardelli (2016). Enhancing sustainability of a processing tomato cultivation system by using bioactive compost teas. Scientia Horticulturae 202:117-124

Salama, R.A.K. and S. Elnagar (2002). The tortoise beetle, Cassida vittata Vill. (Col. Chrysomelidae), a possible pest of sugar beet plantations in Egypt. J.App. Ent 113:88-92 beet varieties. Annals of Agric. Sc., Moshtohor, 41 (3): 1071-1088.

Shalaby, N.M.S., A.H.S.A. Al-Labbody and S.R.E. El-Sheikh (2008). Covariability of yield and quality of twenty sugar beet genotypes. Egypt. J. Plant Breed., 12 (1): 267-277.

Snedecor, G.W. and W.G. Cochran (1981). Statistical methods $6^{\text {th }}$ Ed. Iowa State Univ. Press. Ames. Iowa., USA.

Steve, D. (2009). Compost tea frequently asked questions. www.attar.org.sustainable. Growth, Inc. $2116 \quad$ N. 28 ${ }^{\text {th }}$ Street Boise, ID83703.(C.F.Computer Search).

Sugar Crops Council (2016). Ann. Report Ministry Agric., Egypt. (In Arabic).

Welke, S. E. (2005). The Effect of Compost Extract on the Yield of Strawberries and the Severity of Botrytis cinerea. Journal of Sustainable Agriculture 25(1):57-68. 
إستجابة بعض أصناف بنجر السكر للرش بمنقوع الكمبوست وعلاقة ذلك بالكثافة العددية

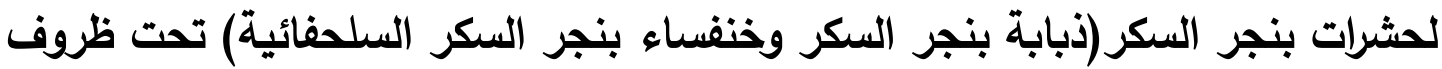
الأراضى الرمليه حديثة الإستصلاح

محمد مصطفى عبد الرحمن(") ، عادل أبو المعاطي أبو الفتوح(") ، محمد عبد المنعم غنيمه(")

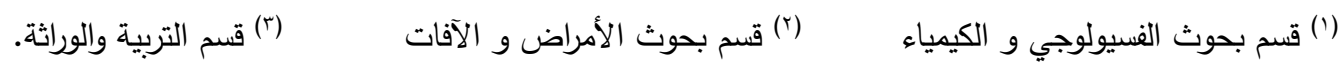
معهة بحوث المحاصيل السكرية - مركز البحوث الزراعية - جيزة الملخص العربى

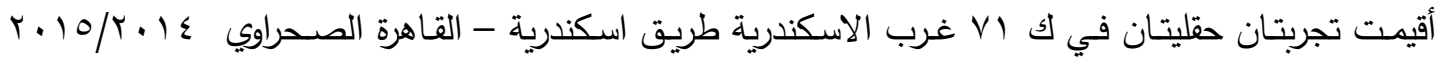

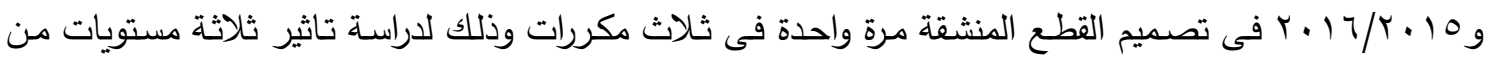

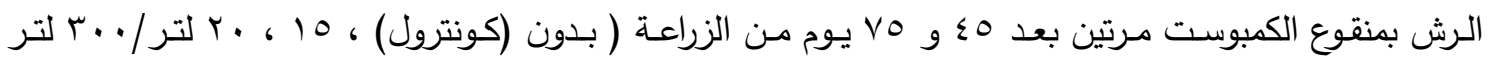

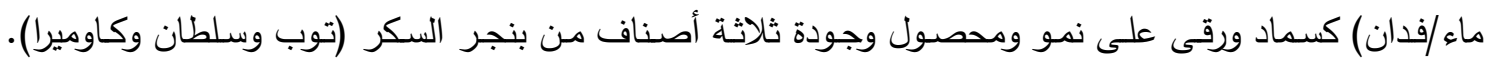

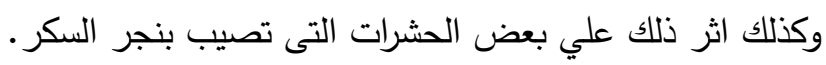

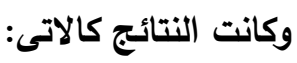

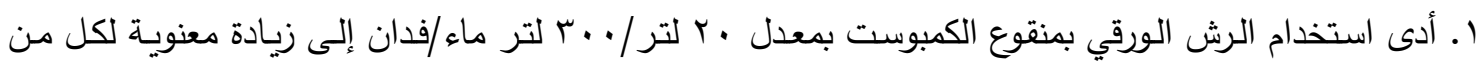

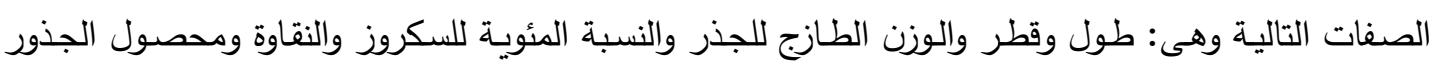
والسكر بينما نقص معنويا محتوى العناصر فى الجذور (الصوديوم والبوتاسيوم والألفا أمينو نيتروجين) بالمقارنة الطنانة بالكنترول (بدون منقوع الكمبوست) فى كلا الموسميين. r. اختلفت الأصناف معنويا فى صفات طول وقطر ووزن الجذر والنسبة المئوية للسكروز والنقاوة ومحصول فئسي

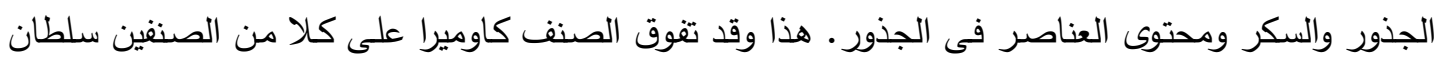
وتوب فى معظم الصفات السابقة فى كلا الموسميين.

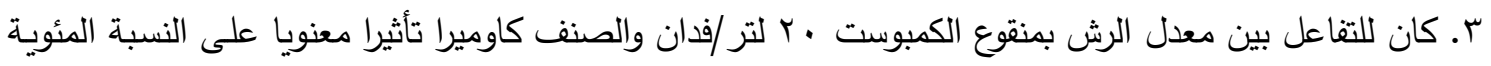

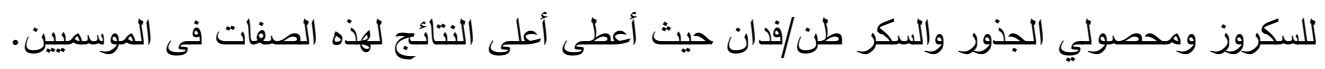

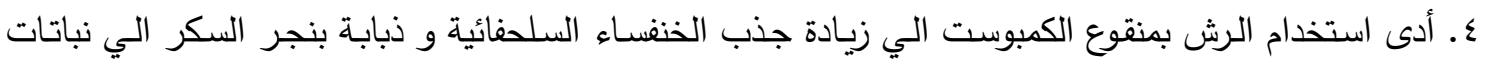
بنجر السكر كما اظهر الصنف كوميرا انه اقل جذبا" للحشرتين تحت الدراسة خلال موسمي الزئل الزراعة حيث سجل اقل تعداد للحشرتين خلال موسمي الزراعة. ه. توصى هذه الدراسة برش أصناف بنجر السكر كاوميرا وسلطان وتوب على التى الترتيب بمنقوع الكمبوست بمعدل

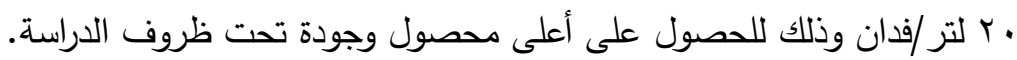


Abd El-Rahman, et al., 